\title{
Teacher Development through Podcast Engagement
}

\section{Matthew W. Turner}

Toyo University

\section{Matthew Y. Schaefer \\ Sophia University}

\section{Robert J. Lowe \\ Tokyo Kasei University}

\section{Reference Data}

Turner, M. W., Schaefer, M. Y., \& Lowe, R. J. (2021). Teacher development through podcast engagement. In P. Clements, R. Derrah, \& P. Ferguson (Eds.), Communities of teachers \& learners. JALT. https://doi.org/10.37546/JALTPCP2020-07

Professional development and community engagement are important parts of maintaining commitment in language teaching. Podcasting is emerging as a form of professional development and engagement with the English language teaching community, both through the production of podcasts themselves, and through participation as listeners. Drawing upon our experiences of creating a podcast, together with an examination of other podcasts in the field, this practically oriented paper will document and identify a range of innovative ways through which engagement with podcasts, by both producers and listeners, can contribute to teacher development. This paper will highlight how podcasts can instigate opportunities for reflective inquiry, aid communities of practice, and support efforts to negotiate practical and theoretical knowledge. After providing a definition of podcasts as a media format and describing their status in the language teaching field, the paper considers professional development opportunities which may be afforded by engagement with podcasts.
言語教育におけるコミットメントを維持するには、専門的な能力開発とコミユニティへの関わりが重要な役割を果たす。ポ ッドキャスティングは、ポッドキャストの制作自体とリスナーとしての参加の両方を通して、非公式で尃門的な能力開発と英語 教育コミユニティとの関わりの一形態として台頭してきた。本論は、過去の経験から、制作者とリスナーの両者がポッドキャス トに関わることにより、教師の能力開発に貢献できるさまざまな革新的方法を記録し、明らかにする。また、ポッドキャストが いかにして内省的な探究の機会を促し、実践のコミユニテイをサポートし、実践的で理論的な知識について議論や交渉する取 り組みを支援できるかという点に光を当てる。メディアの一形態としてのポッドキャストの定義を示し、言語教育分野における ポッドキャストの位置づけを説明した後、ポッドキャストに関わることで得られる可能性のある専門的な能力開発の機会につ いて考察する。

$\mathrm{n}$ a technical level, podcasts are audio files of spoken content that are regularly made available for download on digital devices (see Green \& Brown, 2018). Culturally speaking, over the past two decades, the format has expanded in influence and appeal, and is today considered an innovative, disruptive, and even genre-defining media platform (McHugh, 2016; Spinelli \& Dann, 2019). Due to their portability, accessibility, presentation style, and sense of independence, podcasts have become an invaluable and relevant source of content for a broad range of people (Llinares, Fox, \& Berry, 2018). Throughout the Web 2.0 era, diverse uses for podcasts have emerged in academia and educational fields. For example, they have been examined as an apparatus for formal teacher-centred course content delivery (Middleton, 2016), explored as a mode of informal and progressive learning (Shamburg, 2020), experimented with as a form of student-centred project-based learning (Killean \& Summerville, 2020), discussed as a way to connect and share research with the public (Williams, 2020), and even used as a creative method to generate research (Kinkaid, Emard, \& Senanayake, 2020). In addition, podcast activities offer producers, users, and guests a shared forum for learning and development with one another in a mutually collaborative and engaging fashion.

In English language teaching (ELT) though, podcasting largely remains a burgeoning activity with regard to continuing professional development (CPD). By drawing upon our ongoing personal experiences of creating and producing The TEFLology Podcast, together with surveying other independent podcasting projects in the field of ELT, in this paper we will identify and introduce a variety of approaches for using and engaging 
with podcasts for CPD purposes. By doing so, we hope to support efforts to clearly establish these emerging podcasting activities for both creators and users. Explanations will be provided of different communicative podcasting formats, such as interviews and peer dialogues, particularly in relation to the significance of reflective practice (RP) for teachers' learning and professional growth. In addition, we will explore the potential that podcasts offer ELT in terms of supporting communities of practice (CoP), in which activities with the medium provide spaces for the accessible contribution to, dissemination, and bridging of different areas of knowledge related to the field. Throughout, readers will be directed to time coded segments of the video presentation on YouTube that accompanies this paper, containing audio from podcasting projects that exemplify different points (see Appendix B).

\section{Podcasts in ELT}

Like many other communication technologies, podcasts have contributed to ELT. Primarily, podcasts have been used and considered as tools for language instruction and banks of material resources (Rosell-Aguilar, 2007). Recently though, shifts towards their use as something that language teachers can participate in for the benefit of their own and peers' CPD have emerged. There are now dozens of independent podcast shows being produced by groups of language teaching practitioners (see Appendix A). Although it is not possible to list them all here, we will introduce several in order to provide an overview of the range of shows that are available.

Podcasts are being utilised by language educators to informally discuss a range of topics related to their practice. One such popular podcast is TEFL Commute. Other podcasts that focus on specific themes of interest, such as edtech and teacher training, are The DIESOL Podcast and TEFL Training Institute respectively. Some podcasting practitioners use their shows to conduct interviews with members of the applied linguistics and ELT communities about theoretical work. Along with our own, podcasts like We Teach Languages and Lost in Citations have produced a variety of interviews with researchers about conference presentations, articles, or broader areas of expertise. Other projects, like Unstandardized English, have a more critically oriented emphasis, featuring conversations about race in ELT, for example. Some podcasts, like Teacher Talking Time, see the producers create both content for language learners, as well as opportunities for professional learning for themselves and others. As is the case with our own project, their creation allows for the continuing adaptation and experimentation of different formats and focuses. Many of these shows, as well as others, share overlapping themes of discussion, a mixture of episode types, and inspiration from one another. Moving beyond describing podcasts on a practical level, deeper questions referring to what the medium represents and affords in relation to professional learning theories should also be considered.

\section{Podcast Affordances in Professional Learning}

Podcasting, although heavily discussed as a technology, is really an engagement medium facilitating human interaction and dialogue at its core (Schlütz \& Hedder, 2021). As a predominantly audio-focused platform, Cook (2020) states that, of the key affordances on offer, the presentation of the human voice "is often perceived as an agency laden producer of emotional connections between people" (p. 5). Others, such as Swiatek (2018), observe podcasts as having the ability to operate as an intimate bridging medium, in the way that they help groups to forge links with one another in a shared and accessible mode of speaking and listening. Zuraikat (2020) uses parasocial theory to describe podcasting dynamics, noting a felt sense of relationship and reciprocity between listeners and hosts that is palpable and transcendent. In applied linguistics and related fields, such as ELT, ways to readdress and improve cooperation and understanding between different theory and practice-based members continues to be of prevailing concern (Sato \& Loewen, 2019). Taken as a community of practice, which is broadly considered to be a joint enterprise of members in binding mutual engagement (Wenger, 1998), podcasting offers ELT an interface to support communication. Like a CoP, podcasts emphasise "the discovery of knowledge rather than the delivery of products, services, or tasks", and encompass "organic excitement, discussion, and flexibility among members eager to collectively deepen their knowledge" (Zumach \& Portillo, 2020, p. 1). This is evident not only through the active and auteurist nature of independent podcast production itself, but also through the ability and willingness of guests and listeners to participate in various forms of dialogue and engagement.

As well as helping to maintain a $\mathrm{CoP}$, podcasts also invoke reflective practice opportunities. RP has a number of purposes, but is mostly geared to teachers' navigating moral, critical, cognitive, metacognitive, and practical questions about their profession (Farrell, 2017). In addition, Hayes (2019) sees RP as a shared enterprise that is needed for connecting "the classroom to structures in the school context, the wider community and the socio-economic environment" (p. 158). Podcasts particularly activate dialogic forms of reflection, a mode of reflection that offers a rich approach to constructive professional learning, development, and discourse. Dialogic reflection through the action of podcasting has previously been explored by Turner (2020). 
Continuing professional development for language teachers resides along a continuum from top-down to bottom-up activities, which can be further separated into institutional-based or individual-based activities. In creating podcasts with peers, teacher networks, which are described by Padwad and Parnham (2019) as bottom-up initiatives existing in different scales and aimed at creating "a community to support teachers and encourage the sharing of knowledge through collaboration" (p. 553) are devised. As an example of an open education resource (Blyth \& Thoms, 2021), the listening to and use of podcasts corresponds with the importance of self-selection in CPD processes for teachers (Maggioli, 2020). When materials are well selected and found to be appropriate, a selfdirected personal learning system and knowledge ecology can emerge.

\section{Engagement as Producers}

First, we would like to discuss the impact of podcasting on the professional lives and the professional development of the podcast producers themselves. We will consider the role of podcasting as a mode of RP, a form of research activity, and a way of strengthening and widening a teacher's professional community.

\section{Producing Podcasts for Active Reflection}

When producing podcasts, there are several elements in the process which may contribute to reflection on teaching beliefs and practices. Here we will outline some elements from our own experience of producing a podcast over several years which we feel have been the most salient in this regard.

The first of these is what we have elsewhere termed mini research projects (Lowe, Schaefer, \& Turner, 2017). In order to produce informative and accurate segments on a podcast, it is necessary for the presenters to be well informed on the topics in question. However, nobody is an expert in everything, and for teachers and researchers there are likely to be only one or two narrow areas on which they can claim some expertise. On other topics they will have to get up to speed by reviewing the literature, in the form of books or other academic publications. In effect, for each new segment of the podcast, the presenter responsible will have to conduct a small literature review in order to make sure they have enough knowledge to present coherently about the topic in question. The pressure to regularly produce podcasts to a deadline leads to teachers investigating many topics which they otherwise may never have looked into, thus broadening their knowledge and compelling them to reflect on their beliefs as they come across contradictory or otherwise divergent information. One example of this from our own podcast is the topic of Michael
Lewis and the lexical approach (Lowe, Schaefer, \& Turner, 2019). This was a topic with which we were not very familiar, so one of us prepared for a segment on it by familiarising themselves with both the biography of Lewis and his written work. Without the spur to prepare for the episode, we may not have explored Lewis' work in such depth.

The second reflective element in podcast production involves interaction with your co-presenters, or what we term critical co-presenterships (Lowe, Schaefer, \& Turner, 2017). Farrell (2001) has elsewhere described critical friendships, in which teachers carefully collaborate to closely discuss and reflect on their beliefs and practices in a workplace, and thus develop professionally. Critical co-presenterships play a similar role for podcasters. During the recording of a podcast, presenters may challenge, contradict, and question each other's ideas and statements, leading to critical reflection and re-evaluation of beliefs and practices. This has often happened to us during the recording of our own podcast, where critical discussion has led to newly emerging understandings of concepts, and the rethinking of beliefs. For example, our discussion about the difference between negotiation of and negotiation for meaning led to a much deeper understanding of these concepts (Lowe, Schaefer, \& Turner, in press), an extract of which can be heard in the accompanying video presentation (see Appendix B, [05:50]). As podcasts are freely available to the public, the effects of a critical co-presentership may be different to those of a critical friendship, which are often conducted privately. The audience listening to a podcast at home will hear these discussions, triggering their own reflections, internalisations, and responses. Reflecting through podcasting may also be a solo affair, with some using the medium to present their thoughts through monologue, such as Tim Hampson on the ELT WTF podcast (see Appendix B, [06:47]).

A final reflective element comes directly from the audience. It is common for podcasts to solicit listener feedback, and this feedback can contribute to an ongoing discussion. Perhaps the most common form of direct audience feedback is through email. We have on occasion received correspondence which has challenged information or opinions that we expressed, or simply added new ideas, both of which have contributed to our understanding of a topic, an example of which can be found in the presentation video (see Appendix B, [11:55]). Another form of audience interaction is social media services such as Twitter, which provide a dialogic forum for people to discuss the episodes once they have been released. We have participated in a number of Twitter discussions, particularly when we have made statements on the podcast that were considered interesting, controversial, or at times not adequately informed (see Appendix B, [18:43]). In summary, audience feedback can lead to a free, organic, and polyvocal form of reflection that is spread through a CoP of language educators and listeners. 
JALT2020

COMMUNITIES OF
TEACHERS \& LEARNERS

\section{Producing Podcasts for Research Activities}

Outside of individual and group reflection, podcasts can play a wider role in the creation and dissemination of research. In this section, we identify three ways in which this can be done.

In terms of research projects, podcasts can be used as a way of generating data. For example, early on in the COVID-19 crisis, we made an open call to our audience for stories about how they had been affected and how they had adapted to the situation. We received a number of replies from listeners, who kindly recorded short audio segments which we compiled into a podcast episode (Lowe, Schaefer, \& Turner, 2020). While this was not a formal project that was legitimized by an academic publisher or institution, it still generated an insightful form of data which shed light on a particular phenomenon.

In terms of disseminating research, this has most commonly been done through podcast interviews with researchers. While academic research is often written in a specific register and locked behind the paywalls of academic publishers, interviews provide a much more open, accessible, and dialogic approach to the dissemination and representation of research findings. Mindful of the short timeframe, researchers have to sum up their ideas concisely and, given the broader audience, do so through comprehensible language. The role of the interviewer is important here, as they can act as the voice of the audience, by asking for clarification of points that are too esoteric or unclear, and pursuing topics until their understanding has been satisfied. This is crucial as it can prevent the interview from becoming bogged down in jargon or moving along so quickly that the audience gets lost. A segment from the We Teach Languages podcast demonstrates interviews in action (see Appendix B, [09:48]).

A second way in which podcasts could contribute to the dissemination of research would be through authorized audio recordings of academic papers. Rather than having to access a paywalled site, listeners could simply download a podcast and listen to the article at any time. This change in modality may contribute to the accessibility and digestibility of the material. In one example from outside ELT, Fox and Llinares' (2018) publication on the topic of cinema innovatively took the form of an audio essay to present most of its content.

\section{Connecting with a Community}

A final way in which producing podcasts may help with the professional development of practitioners is through the development of community. The community of professionals which a practitioner may interact with is known as a personal learning network (PLN) (see Nicholas, et al., 2018). Producing a podcast can create pathways to and connections within such a network. We have found that links have often been made between us and our listeners through online discussion over sites such as Twitter, and also through face-to-face meetings at conferences. These people have become our friends, collaborators, and colleagues, and have contributed to our expanding professional development. Figures 1 and 2 provide brief snapshots of professional collegiality around podcast engagement.

Figure 1

Tweet regarding a guest apperance on a podcast episode (deHaan, 2020)

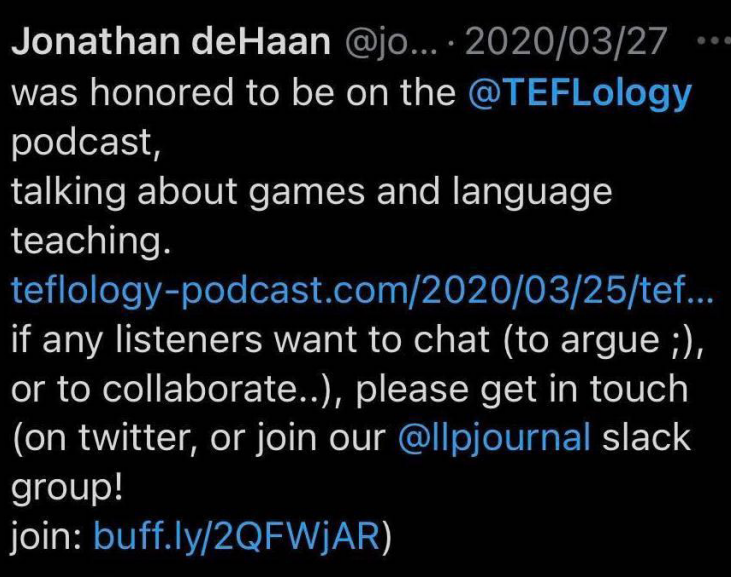


JALT2020

COMMUNITIES OF
TEACHERS \& LEARNERS

Figure 2

Tweet Regarding Participating in a Podcast Roundtable Discussion (Bruzzano, 2020)

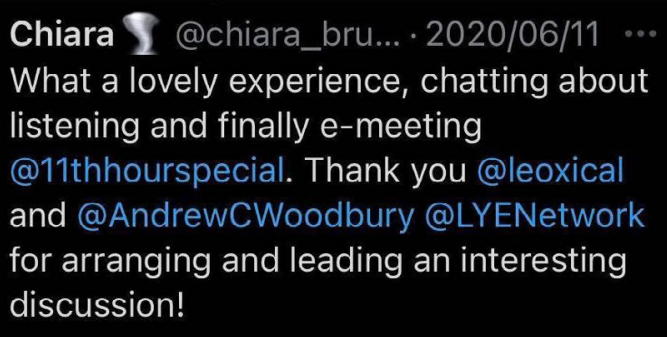

6. TeacherTalkingTi... · 2020/06/10

Recording a round table episode

tomorrow with @11thhourspecial,

@chiara_bruzzano, @leoxical and

@AndrewCWoodbury! We'll talk the

state of listening in \#ELT and what

the future holds. Very excited about

this one!

\#podcast \#podcasting \#ELT \#CPD

\#listening

\section{Engagement as Listeners}

We would now like to look at the other side of the engagement brought about with the spoken medium, for example the listeners and how their involvement with podcasts can also lead to CPD affordances. Before that, however, we will consider and look at some examples of how podcasts as spoken texts are distinct from their written text counterparts.

\section{Podcasts as Spoken Texts}

Simply choosing to listen to a podcast episode is a form of engagement in the same way that choosing to read an academic text is. However, the different forms of media result in different types of formats, formality, and distribution, which means that each has separate features that may make them appealing in terms of playing a part in a teacher's CPD.

The reasons people listen to podcasts can be broadly divided into two main categories: for entertainment and for education. These are, of course, not mutually exclusive. In the first category, listeners may find a podcast humorous, relatable, and likable. In the second category, some benefits may include being introduced to a new topic, hearing new ideas on a familiar topic, or being challenged on previous assumptions. In the field of language education, not many written equivalents to the spoken medium of a podcast exist outside of those published in journals or books, neither of which typically attempt to be entertaining for the reader (which is not to say that they cannot be engaging). This means that the spoken text created by a podcast may be more dynamic, accessible, and approachable to most teachers.

A related feature of podcast episodes is their formality. This is expressed in several ways, mostly connected to the fact that they are usually semi-structured, dialogic, and exploratory. As mentioned in the previous section, the producers of podcasts will often research a topic before recording an episode; however, this preparation is often used only as the starting point, or signposts along the way, of the recorded discussion. What results is a text that can be described as informed spontaneity, in which ideas are introduced, examined, and challenged in real time. This is most evident in dialogue among multiple podcast presenters, who can bring different perspectives to a topic and work together to co-create meaning and make new discoveries through their interactions. A spoken text featuring this kind of exploration of a topic, with possible dead ends, repetitions, and redundancies, is clearly not as structured as a written text describing a piece of exploratory research.

The less formal nature of podcasts also means that they are typically, though not always, less academic than a journal article or book chapter. Podcasts are therefore less likely to use jargon, so understanding will be less reliant on specialist knowledge. In addition, because many podcasts feature spoken interaction, the hosts are more immediately focused on making themselves comprehensible to each other, which includes efforts to repair any breakdowns in communication. All of this potentially leads to a text that might be more approachable, and less cognitively demanding to listeners, compared to a written academic text (see Kennedy et al., 2016).

Finally, there are two practical differences that make podcasts more accessible than journal articles or books. The first is their portability. It is possible to listen to a podcast episode during a commute to work or while engaged in other activities such as exercising
M FRONT PAGE

$<$ PREVIOUS PAGE

NEXT PAGE >
FULL SCREEN 
or household chores. The second is price. While many journals require subscriptions and books must be purchased, podcasts are for the most part completely free of any charge.

\section{Podcasts as Self-directed CPD Resources}

We will now look at how a podcast can be used for informal professional development, which in this context means that it is self-initiated, open-ended, and intrinsically selfdirected.

The initial and most straightforward way of engaging with podcasts is to search for episodes on a topic of interest. This could be something very practical related to one's current teaching practice or something more theoretical that may be the starting point of future research. The growing number of language education podcasts means that you are likely to find a variety of voices on any given topic. As an example, a search on the Apple Podcast app of the term CLIL (content and language integrated learning) leads to 16 different episodes in 14 separate podcast feeds in four different languages (see Appendix $\mathrm{B},[17: 11])$.

The decision to listen to a podcast requires an intrinsic level of commitment, selfdirection, and motivation. Although podcasts are a publicly available resource, the act of listening to one is often solitary, individualized, and intimate. Having spent time selecting episodes, and prior to any follow up responses that may take place, the occasion of simply listening to a podcast as it plays out, whether it is as part of multitasking or as the main activity, is a form of CPD engagement for listeners. The listening habits of users as they aurally interact with a podcast dialogue is difficult to pin down and describe, given that it is largely taking place internally and independently in the moment. However, podcast listening may prompt behaviours, including physical expressions like pausing, repetition, and note-taking, and metacognitive processes, such as self-talk, reflection, and realisation.

Further engagement may take the form of consolidating new insights and knowledge. One way to do this is by engaging in follow-up reading. Podcasts will often provide suggestions for journal articles or book chapters to read to learn more about the ideas that were discussed. Another form of post-listening engagement is to participate in dialogue about the topics that you have listened about. This could happen after both you and a peer have listened to the same podcast episode. You could then discuss what you took from it, including agreement or disagreement with the opinions expressed by the hosts, or new lesson activities that you might try, as well as co-creating your own understandings about the topic. This engagement can also take place online, as many podcasts have social media accounts that provide a space for their audience to share responses to what they heard. One approach to knowledge consolidation is provided by the We Teach Languages podcast, in which a newsletter is used to spur written listener reflections through social media, with the newsletter itself acting as a repository for these responses and takeaways. (Hawkins \& Johnson, 2020).

Finally, engagement as a listener can be in dialogue with the podcast producers. This may include contacting the producers directly to share opinions, ask questions about a topic, or challenge some of the ideas that were expressed. Many podcasts will read such correspondence in subsequent episodes, which can result in further discussion. Some podcasts even invite audience members to contribute to episodes, thus blurring the line between producer and listener.

\section{Podcasts Within Formal CPD Settings}

In contrast to the informal CPD discussed earlier, formal CPD is typically assigned by someone, is time sensitive, and/or is intended to result in an assignment submission, a presentation, or a publication. Podcasts as formal resources are often used in a similar way to academic written texts. For example, it is becoming more common to employ them as part of the background reading for a piece of research and/or to cite them as references when writing a journal article, book chapter, or book. Similarly, trainers of teaching qualification courses or professors of degree courses may assign relevant podcast episodes in preparation for looking at a particular aspect of teaching practice or theory.

In addition, teacher trainers or anyone running a faculty development session can use podcasts in a very similar way to how they might use a written text. One example would be to provide pre-listening questions for teachers to discuss collectively, or consider individually, before they listen to an episode, and then offer post-listening questions for further discussion or consideration. Listening to a podcast episode could also be a prompt for participants to record their own discussion about a topic and share those recordings with other groups. For example, podcasts are being utilised in a related way at the University of South Wales in the UK, in which The TEFLology Podcast is offered to TESOL students as reference material for undergraduate theses writing. Also, a collaborative arrangement between the Teacher Talking Time podcast and Carleton University in Canada, has facilitated opportunities for student-produced interviews with researchers as part of an MA applied linguistics course. 
JALT2020

COMMUNITIES OF
TEACHERS \& IEARNERS

\section{Conclusion}

This article has outlined the roles that podcasts can play in sustaining engagement in the language teaching profession, maintaining communities of practice, promoting reflective practice, and facilitating an interface for knowledge and research exchange. Although the aim of this paper was not to empirically assess the significance of the platform in this field, we hope that the practical examples and descriptions presented here not only indicate that podcast involvement, as producers or listeners, may have some beneficial effects, but also pique readers' interest in considering podcast activities as being an option for professional and community engagement in ELT.

\section{Bio Data}

Matthew W. Turner is an English language lecturer at Toyo University, Tokyo. His research interests include reflective practice, professional development, podcasting, accessible tourism, and support for language learners with disabilities. <turner@toyo.jp> Matthew Y. Schaefer is a lecturer at Sophia University, Tokyo. His research interests include curriculum design, program evaluation, teacher education, and speaking assessment. <myschaefer1920@gmail.com>

Robert J. Lowe is anassociate professor in the Department of English Communication at Tokyo Kasei University. His professional interests include ideology in language education, and qualitative methodology in applied linguistics research. <robert-1@tokyokasei.ac.jp>

\section{References}

Blyth, C. S., \& Thoms, J. J. (2021). Open education and second language learning and teaching. Multilingual Matters.

Bruzzano, C. [@chiara_bruzzano]. (2020, June 11). What a lovely experience, chatting about listening and finallye-meeting@11thhourspecial.Thank you @leolexical and @AndrewCWoodbury@ LYENetwork for arranging and [Tweet]. Twitter.

Cook, I. M. (2020). Critique of podcasting as an anthropological method. Ethnography, 0(0), 1-19. https://doi.org/10.1177/1466138120967039

deHaan, J. [@jonathandehaan]. (2020, March 27). Was honored to be on the @TEFLology podcast, talking about games and language teaching. teflology-podcast.com/2020/03/25/tef... if any listeners want to [Tweet]. Twitter.
Farrell, T. S. C. (2001). Critical friendships: Colleagues helping each other develop, ELT Journal, 55(4), 368-374, https://doi.org/10.1093/elt/55.4.368

Farrell, T. S. C. (2017). Research on Reflective Practice in TESOL. Routledge.

Fox, N., \& Llinares, D. (2018). Cinematologists: Knowing sounds. Media Practice and Education, 19(1), 48-51. https://doi.org/10.1080/14682753.2017.1362170

Green, T. D., \& Brown, A. H. (2018). The educator's guide to producing new media and open educational resources. Routledge.

Hayes, D. (2019). Continuing professional development/continuous professional learning for English language teachers. In S. Walsh \& S. Mann (Eds.), The Routledge Handbook of English Language Teacher Education (pp. 155-168). Routledge.

Hawkins, M., \& Johnson S. M. (2020, July 22). Podcasts for language teachers: Supercharge your professional development! [Conference session]. NFLC Virtual Summit 2020, Maryland. https:// www.youtube.com/watch?v=UM156igjWs8\&feature=emb_title

Kennedy, M. J., Hirsch, S. E., Dillon, S. E., Rabideaux, L., Alves, K. D., \& Driver, M. K. (2016). Using content acquisition podcasts to increase student knowledge and to reduce perceived cognitive load. Teaching of Psychology, 43(2), 153-158. https://doi.org/10.1177/0098628316636295

Killean, R., \& Summerville, R. (2020). Creative podcasting as a tool for legal knowledge and skills development. The Law Teacher, 54(1), 31-42. https://doi.org/10.1080/03069400.2019.1568675

Kinkaid, E., Emard, K., \& Senanayake, N. (2020). The podcast-as-method? Critical reflections on using podcasts to produce geographic knowledge. Geographical Review, 110(1-2), 78-91. https:// doi.org/10.1111/gere.12354

Llinares, D., Fox, N., \& Berry, R. (2018). Podcasting: New Aural Cultures and Digital Media. Springer. Lowe, R. J., Schaefer, M. Y., \& Turner, M. W. (2017). Podcasting and professional development: A guide for English language teachers. The Round. Available from http://the-round.com/resource/ podcasting-and-professional-development/

Lowe, R. J., Schaefer, M. Y., \& Turner, M. W. (Hosts). (2019, May 1). Episode 87: Michael Lewis, IATEFL, and Visual Aids [Audio Podcast Episode]. In The TEFLology Podcast. https://teflologypodcast.com/2019/05/01/episode-87-michael-lewis-iatefl-and-visual-aids/

Lowe, R. J., Schaefer, M. Y., \& Turner, M. W. (Hosts). (2020, April 10). Episode 98: Emergency Remote Teaching Responses [Audio Podcast Episode]. In The TEFLology Podcast. https:// teflology-podcast.com/2020/04/10/episode-98-emergency-remote-teaching-responses/

Lowe, R. J., Schaefer, M. Y., \& Turner, M. W. (2021). Dialogic research engagement through podcasting as a step towards action research: A collaborative autoethnography of teachers exploring their knowledge and practice. Educational Action Research, 1-18. https://doi.org/10.10 $80 / 09650792.2021 .1908905$ 


\section{JALT2020}

COMMUNITIES OF
TEACHERS \& IEARNERS
Maggioli, G. D. (2020). Continuous professional development: The seeds of professionalism. In C. Coombe, N. J. Anderson, \& L. Stephenson (Eds.), Professionalizing Your English Language Teaching (pp. 253-262). Springer.

McHugh, S., (2016). How podcasting is changing the audio storytelling genre. The Radio Journal: International Studies in Broadcast and Audio Media, 14(1), 65-82. https://doi.org/10.1386/ rjao.14.1.65_1

Middleton, A. (2016). Reconsidering the role of recorded audio as a rich, flexible and engaging learning space. Research in Learning Technology, 24. https://doi.org/10.3402/rlt.v24.28035

Nicholas, B., Avram, A., Chow, J., \& Lupasco, S. (2018). Building a community of connected ELT professionals on Twitter. TESL Canada Journal, 35(2), 166-178. https://doi.org/10.18806/tesl. v35i2.1296

Rosell-Aguilar, F. (2007). Top of the pods: In search of a podcasting "podagogy" for language learning. Computer Assisted Language Learning, 20(5), 471-492. https://doi. org/10.1080/09588220701746047

Sato, M., \& Loewen, S. (2019). Do teachers care about research? The research-pedagogy dialogue. ELT Journal, 73(1), 1-10. https://doi.org/10.1093/elt/ccy048

Schlütz, D., \& Hedder, I. (2021): Aural parasocialrRelations: Host-listener relationships in podcasts, Journal of Radio \& Audio Media. https://doi.org/10.1080/19376529.2020.1870467

Shamburg, C. (2020). Rising waves in informal education: Women of color with educationally oriented podcasts. Education and Information Technologies, 1-15. https://doi.org/10.1007/ s10639-020-10284-3

Spinelli, M., \& Dann, L. (2019). Podcasting: The audio media revolution. Bloomsbury.

Swiatek, L. (2018). The podcast as an intimate bridging medium. In D. Llinares, N. Fox, \& R. Berry (Eds.), Podcasting: New Aural Cultures and Digital Media (pp. 173-187). Springer.

Turner, M. W. (2020). Podcasting: Spaces for connection and development. In P. Clements, A. Krause, \& R. Gentry (Eds.), Teacher efficacy, learner agency. (pp. 32-39) JALT. https://doi. org/10.37546/JALTPCP2019-05

Wenger, E. (1998). Communities of practice: Learning as a social system. Systems Thinker, 9(5). Retrieved from https://thesystemsthinker.com/communities-of-practice-learning-as-a-socialsystem/

Williams, L. (2020). Political science and podcasts: An introduction. PS: Political Science \& Politics, 53(2), 319-320. https://doi.org/10.1017/S1049096519001677

Zumach, G. M., \& Portillo, E. (2020). Cultivating a community of practice through podcasting. Innovations in pharmacy, 11(1), 1-6. https://doi.org/10.24926/iip.v11i1.2932

Zuraikat, L. (2021). The parasocial nature of the podcast. In J. A. Hendricks (Ed.), Radio's second century. (pp. 39-52). Rutgers University Press.

\section{List of Podcasts}

- The DIESOL Podcast - http://diesol.org/

- Lost in Citations - https://www.lostincitations.com/

- Teacher Talking Time - https://teachertalkingtime.podbean.com/

- TEFL Commute - http://www.teflcommute.com/

- The TEFLology Podcast - https://teflology-podcast.com

- TEFL Training Institute - https://www.tefltraininginstitute.com/podcasts

- Unstandardized English - https://anchor.fm/unstandardized

We Teach Languages - https://weteachlang.com/

\section{Appendix B}

Link to Video Presentation on YouTube

- Turner, M. W., Schaefer, M. Y., \& Lowe, R. J. (2020, November 3). Teacher Development Through Podcast Engagement [Video]. YouTube. https://www.youtube. com/watch?v=7lvCHuXK7cg 